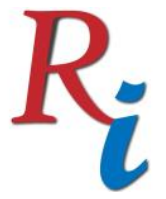

Asia Proceedings of Social Sciences

(APSS)

www.readersinsight.net/APSS

\title{
DEVELOPMENT AND VALIDATION OF A VOCATIONAL LEARNING STYLES INSTRUMENT USING THE RASCH MEASUREMENT MODEL
}

\author{
Mazlili Suhaini $^{\star}$
}

School of Education

Universiti Teknologi Malaysia (UTM)

Malaysia

Adnan Ahmad

School of Education

Universiti Teknologi Malaysia (UTM)

Malaysia

Normila Mohd Bohari

School of Education

Universiti Teknologi Malaysia (UTM)

Malaysia

\section{Norliza Mohamad}

School of Education

Universiti Teknologi Malaysia (UTM)

Malaysia

*Corrosponding author’s Email: mazlili.2385@gmail.com

Peer-review under responsibility of 5 th $^{d}$ Asia International Conference 2019 Scientific Committee http://connectingasia.org/scientific-committee/

(C) 2019 Published by Readers Insight Publisher, lat 306 Savoy Residencia, Block 3 F11/1,44000 Islamabad. Pakistan,

editor@readersinsight.net

This is an open access article under the CC BY-NC-ND license (http://creativecommons.org/licenses/by-nc-nd/4.0/). 


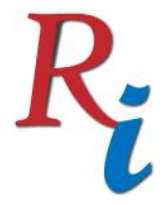

Asia Proceedings of Social Sciences

(APSS)

www.readersinsight.net/APSS

\section{A b s t r a c t}

Malaysia is considered one of the developing countries undergoing rapid economic development over the past five decades. As a developing country with a rapidly growing population, providing the citizens with comprehensive and updated knowledge is crucial for the country, particularly in vocational training. A number of vocational and technical training have been developed. However, the success of vocational education relies on the capability of instructors or teacher's approach to achieve the goals. It is important to create appropriate method that take into consideration their students' learning styles to get better outcome. Therefore, the purpose of this paper is to develop vocational learning styles instrument. Empirical evidence on the validity and reliability of modified items has been done. A survey of 57 Electrical Technology students were distributed. The Rasch measurement model was used to examine the functional items and detect the item and respondent reliability and index separation, the polarity of item, measuring the fit of item in measuring the construct and standardised residual correlation values.

\section{Rese a r ch H igh I ight s}

This research is to determine the validity, and reliability of the 35 items in the four (4) constructs of vocational learning style in accordance with the Rasch measurement model's procedures of the reliability analysis of an item. Learning is a productive process that influences how learners approach studying, and it is diverse from one person to another person. It is clear that each individual has his or her own learning style. The final findings show that only four items did not meet the criteria and 31 items remained suitable to measure the four constructs.

\section{Research Objectives}

This study is aimed to fulfil the development an instrument of vocational learning styles. This instrument will help the educators to investigate their students learning styles in order to select a suitable teaching strategy or approach that focused on the students' learning style. Therefore, this study is specifically driven by the following research objectives which are to identify the items and person reliability and separation index in the instrument, to identify the polarity of 


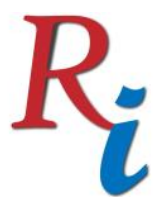

\section{Asia Proceedings of Social Sciences}

(APSS)

www.readersinsight.net/APSS

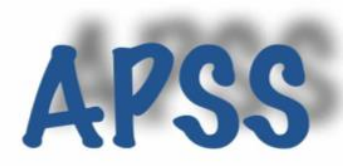

items adequacy in the instrument, to identify the item's fit in the definition of learning style of the instrument and lastly to identify dependant items based on standardizes residual correlation values.

\section{Methodology}

A sample of 60 students was chosen for the pilot study and distributed to the Electrical Technology students in classes after obtaining the approval from the Education Planning and Research Division (EPRD), Department of Technical and Vocational Education (BPTV), College Director and lecturer's permission. Of the 60 instruments distributed, 57 instruments were returned. This study uses a quantitative approach which uses questionnaire as an instrument. The instrument consists constructs involving four learning styles which are active, sensing, visual and sequential. The questionnaire had undergone a process of face-to-face and content evaluation with an appointed expert to establish the validity of the construct. Validity is an important concept of measuring a construct. According to Darusalam and Hussin, (2018), the validity of a measurement depends on how well it measures what it aims to measure. Therefore, a total of 3 specialists with doctorate degrees in Philosophy in the field of Psychology and Technical and Vocational Education with over five years of experience were appointed as the panel experts to evaluate the validity of the instrument. The data was analysed using Winsteps version 3.72.3 on the basis of a Rasch measurement model. The Rasch measurement model is capable of performing a thorough and detailed examination of each item as opposed to just the Alpha Cronbach's values. According to (Yusoff et al., (2018), the researchers conducted four diagnoses to perform the item functional inspection, namely item reliability and separation index, detecting the polarity of an item to measure the construct based on PTMEA CORR, testing the suitability of an item by measuring the construct and lastly to determine the dependant item based on the standardised residual correlation values

\section{Results}

The reliability of the item was 0.82 , while the separation index of item was 2.10 . Based on Bond and Fox, (2007), the reliability value of 0.82 is good and acceptable. The separation index indicates that the value that is accepted by Linacre, (2012) and on Bond and Fox, (2007) is more than 2.0. the reliability of person was 0.87 , while the separation index of person was 2.64 . 


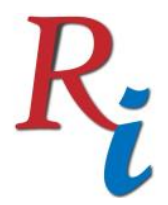

Asia Proceedings of Social Sciences

(APSS)

www.readersinsight.net/APSS

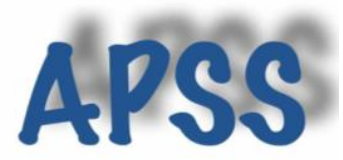

the polarity item which analysed using the Point Measure Correlation (PTMEA CORR) were all in positives values. these verify that the items developed by the researcher actually measure the construct. There were four items exceeds the value of $0.5-1.50$ in the outfit total mean square (MNSQ) and the value of standardized fit (ZSTD) exceeds the range of \pm 2 . on Bond and Fox, (2007) claim that the value infit and outfit ZSTD should be in the range of -2 to +2 . However, if the infit and outfit MNSQ values are accepted, the ZSTD values can be ignored (Linacre, 2012). There were 10 pairs of standardised residual correlation, however these correlation values does not exceed 0.7 and will be remained.

\section{Findings}

Some modifiation were considered to further strengthen the instrument, especially to the four items need to be removed as the measurement of outfit MNSQ and the ZSTD exceeds the range value given. After the validation and reliability testing, the final version of the instrument consists of four constructs: active ( 8 items), sensing ( 7 items), visual ( 8 items) and sequential ( 8 items). Total of 35 items will be used for the real research. The data obtained from the established instrument could also be used to develop a vocational learning style framework that could help the BPTV and curriculum planner to plan better in terms of the course development, course delivery, learning activities and assessment as these are the most impactful modifications required in the curriculum.

\section{References}

Bond, T.G., Fox, C.M., 2007. Applying the rasch model: fundamental measurement in the human sciences, 2nd Editio. ed. Lawrence Erlbaum Associates, New Jersey.

Darusalam, G., Hussin, S., 2018. Metodologi penyelidikan dalam pendidikan: amalan dan analisis kajian, 2nd ed. Penerbit Universiti Malaya, Kuala Lumpur.

Linacre, J.M., 2012. A user's guide to WINSTEPS MINISTEP, 3.74.0. ed, Winsteps.

Yusoff, H.M., Hamzah, M.I., Surat, S., 2018. Kesahan dan kebolehpercayaan instrumen indeks pemupukan kreativiti dalam pengajaran guru dengan elemeni islam ( I-CFTI ) berdasarkan pendekatan model rasch. J. Pendidik. Malaysia 1, 77-88. 


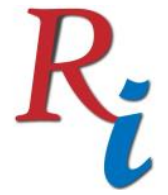

\section{Asia Proceedings of Social Sciences}

(APSS)

www.readersinsight.net/APSS

Author's Biography

MAZLILI SUHAINI is a postgraduate student currently studying in technical and vocational education at Universiti Teknologi Malaysia (UTM). The research was conducted on the development and validation of a vocational learning styles instrument using rasch measurement model, 